\title{
A systematic mapping study on the development of permeable reactive barrier for acid mine drainage treatment
}

\author{
April Anne Tigue ${ }^{1}$, Roy Alvin Malenab ${ }^{1}$ and Michael Angelo Promentilla ${ }^{1, *}$ \\ ${ }^{1}$ Department of Chemical Engineering, Gokongwei College of Engineering, De La Salle University, 2401 Taft Avenue, Manila, 1004, \\ Philippines
}

\begin{abstract}
Acid mine drainage is a result of exposure of sulfide ore and minerals to water and oxygen. This environmental pollutant has been considered the second biggest environmental problem after global warming. On the other hand, permeable reactive barrier is an emerging remediation technology which can be used to treat acid mine drainage. However, the effectiveness of this proposed remediation technology greatly depends on the reactive media. Also, treatment of acid mine drainage using permeable reactive barrier is still in the infancy stage, and long-term performance is still unknown. Hence, this study was conducted to identify what have been studied, addressed and what are currently the biggest challenges and limitations on the use of permeable reactive barrier for acid mine drainage treatment. Through systematic mapping approach, the results have shown that the reactive media used in permeable reactive barrier can be categorized into five namely iron-based, organic-based, inorganic minerals-based, industrial waste-based, and combined media. The data revealed that majority of the papers which is about $40 \%$ use combined media as the reactive substrate. The future direction is toward the use of combined media as a reactive material for AMD treatment, for instance, use of geopolymer with mine tailings and silts as reactive media in combination with organic-based media.
\end{abstract}

\section{Introduction}

Acid mine drainage (AMD), also known as acid rock drainage (ARD), is a result of the reaction of oxygen and water with sulfide minerals commonly in the form of pyrite. It has a low $\mathrm{pH}$, high salinity, and high heavy metal toxicity [1]. The resulting waste is an environmental pollutant associated with mining activities which can contaminate both ground and surface water [2]. AMD normally contains ferric, ferrous, sulfate ions, and other cationic metallic elements such as $\mathrm{Mn}, \mathrm{Al}, \mathrm{Ni}$, $\mathrm{Cu}$, and $\mathrm{Zn}$ in various concentration. These solutes can be detrimental to the environment. In fact, the United Nations has considered AMD as the second biggest environmental problem after global warming [3]. In addition, the generation of AMD starts from the mining operation and continues even after mine closure and/or abandonment. The reaction mechanism involved in AMD generation in the form of pyrite as sulfide mineral is shown in Reactions R1-R5.

Oxidation of Pyrite forms ferrous iron and sulfate:

$\mathrm{FeS}_{2}+\mathrm{O}_{2}+\mathrm{H}_{2} \mathrm{O} \rightarrow \mathrm{Fe}^{2+}+2 \mathrm{SO}_{4}^{2-}+2 \mathrm{H}^{+}$

Ferrous iron is further oxidized to ferric iron in the presence of iron-oxidizing bacteria:

$$
\mathrm{Fe}^{2+}+0.25 \mathrm{O}_{2}+\mathrm{H}^{+} \rightarrow \mathrm{Fe}^{3+}+0.25 \mathrm{H}_{2} \mathrm{O}
$$

Spontaneous reaction of ferric iron with water to form ferric hydroxide (orange-red precipitate):

$$
\mathrm{Fe}^{3+}+3 \mathrm{H}_{2} \mathrm{O} \rightarrow \mathrm{Fe}(\mathrm{OH})_{3}+3 \mathrm{H}^{+}
$$

Excess $\mathrm{Fe}^{3+}$ serves as an additional and secondary reducing agent for pyrite:

$$
\mathrm{FeS}_{2}+14 \mathrm{Fe}^{3+}+8 \mathrm{H}_{2} \mathrm{O} \rightarrow 15 \mathrm{Fe}^{2+}+2 \mathrm{SO}_{4}{ }^{2-}+16 \mathrm{H}^{+}
$$

The resulting overall reaction produces sulfuric acid and ferric hydroxide:

$$
\mathrm{FeS}_{2}+3.75 \mathrm{O}_{2}+\underset{4 \mathrm{H}^{+}}{3.5 \mathrm{H}_{2} \mathrm{O}} \rightarrow \mathrm{Fe}(\mathrm{OH})_{3}+2 \mathrm{SO}_{4}{ }^{2-}+
$$

AMD treatment can be classified into two- active and passive technique. The active treatment involves continuous addition of alkali to increase the $\mathrm{pH}$ and subsequent removal of metals. The passive treatment, on the other hand, uses natural and biological processes. Various prevention and treatment techniques include lime neutralization, passivation, in-situ biological remediation, backfilling, waste heap-covers, constructed wet lands, and permeable reactive barrier. Among these techniques, the most promising is the use of permeable reactive barrier for AMD treatment.

The treatment of AMD can either be physical, chemical, or biological using this technique. PRB is an emerging remediation technology for AMD treatment which is a low-cost in-situ treatment, prevents crosscontamination with surface waters, prevents loss of large amounts of groundwater, has no land space required, and doesn't require any waste disposal [1]. However, the performance of PRB on AMD treatment is dependent on

\footnotetext{
*Corresponding author: michael.promentilla@dlsu.edu.ph
} 
Process Steps

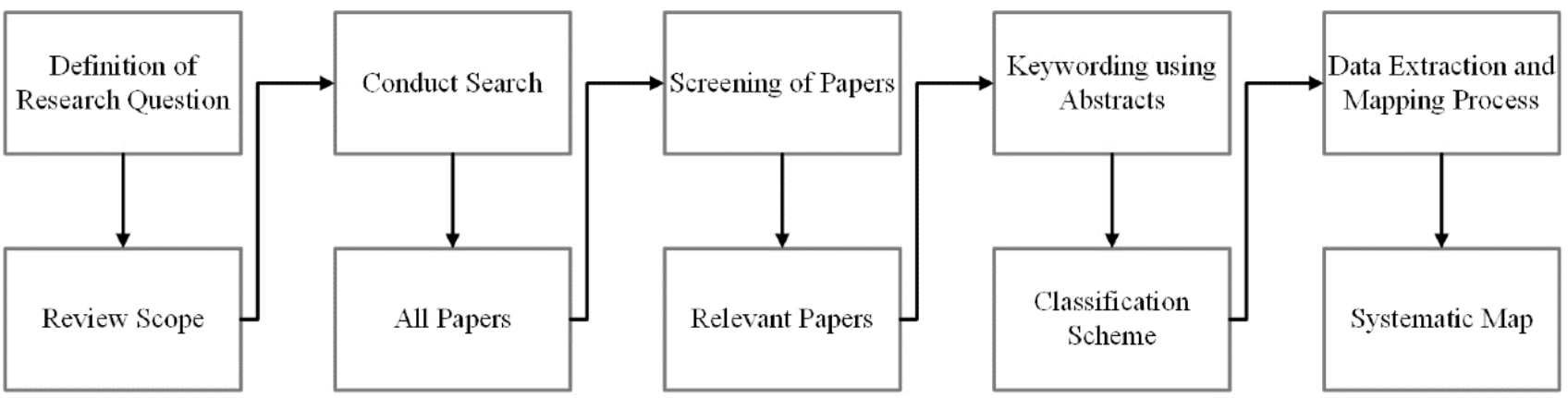

Outcomes

Figure 1. Systematic mapping process [5].

the substrate used. In addition, PRB is still in the infancy stage for AMD treatment, and long-term performance is still unknown.

Hence, this study aims to identify the biggest challenges and limitations encountered on the use of PRB to treat AMD through systematic mapping approach.

\section{Materials and methods}

Systematic mapping study aims to provide an overview of a research area, to establish existence of research evidence, and quantify the amount of evidence [4]. In this study, the researcher follows the systematic mapping process [5]. The systematic mapping process was chosen as research methodology because the aim was to explore the existing studies related to PRB for AMD treatment. The results of the mapping study would help us to identify and map research areas related to PRB for AMD treatment and possible research gaps. The process for the systematic mapping study is illustrated in Error! Reference source not found..

\subsection{Definition of research question}

The first step in systematic process is definition of research question. In this study, the three defined questions are as follows:

2.1.1 What topics have been addressed in current research on PRB for AMD treatment?

2.1.2 What approaches/techniques have been developed on PRB for AMD treatment?

\subsection{Conduct search}

The second stage of mapping is to search for all relevant papers related to the study. A search protocol has been defined in the study in which it is limited to search papers containing the identified keywords in the abstract. The keywords used were acid mine drainage, AMD, mine drainage, mine drain*, permeable reactive barrier, permeable reactive treatment zone, and PRTZ as the search string. The asterisk (*) was used to broaden the search result. The researchers decided to use the Scopus as the database to search for all relevant papers related to the study.

\subsection{Screening of relevant papers}

The third stage of mapping is to screen all the relevant papers resulted using the search protocol since not all papers are relevant. The papers were screened based on the title.

\subsection{Keywording}

The next step in mapping process is to classify relevant papers by reading the abstract.

\subsection{Data extraction and mapping}

The last step in mapping process is to extract relevant information necessary to address the research questions. In addition, quantification was also performed the have an overview of the current research related to the study.

\section{Results and discussion}

\subsection{Basic Information of the papers}

The defined search protocol has returned a 78 papers search results as preview shown in Figure 2. Majority of the study were published as article paper $(62.80 \%)$. There are 23\% papers presented at conferences (Figure 3a and 3b). Other papers were published as review paper, book chapter, erratum, an article in press, and short survey.

Out of the 78 papers, 65 papers were found to be relevant. The papers were then classified based on the reactive media such as iron-based $\mathrm{PRB}$, organic-based $\mathrm{PRB}$, inorganic minerals-based $\mathrm{PRB}$, industrial wastebased PRB, and combine media PRB as shown in Figure 4. 


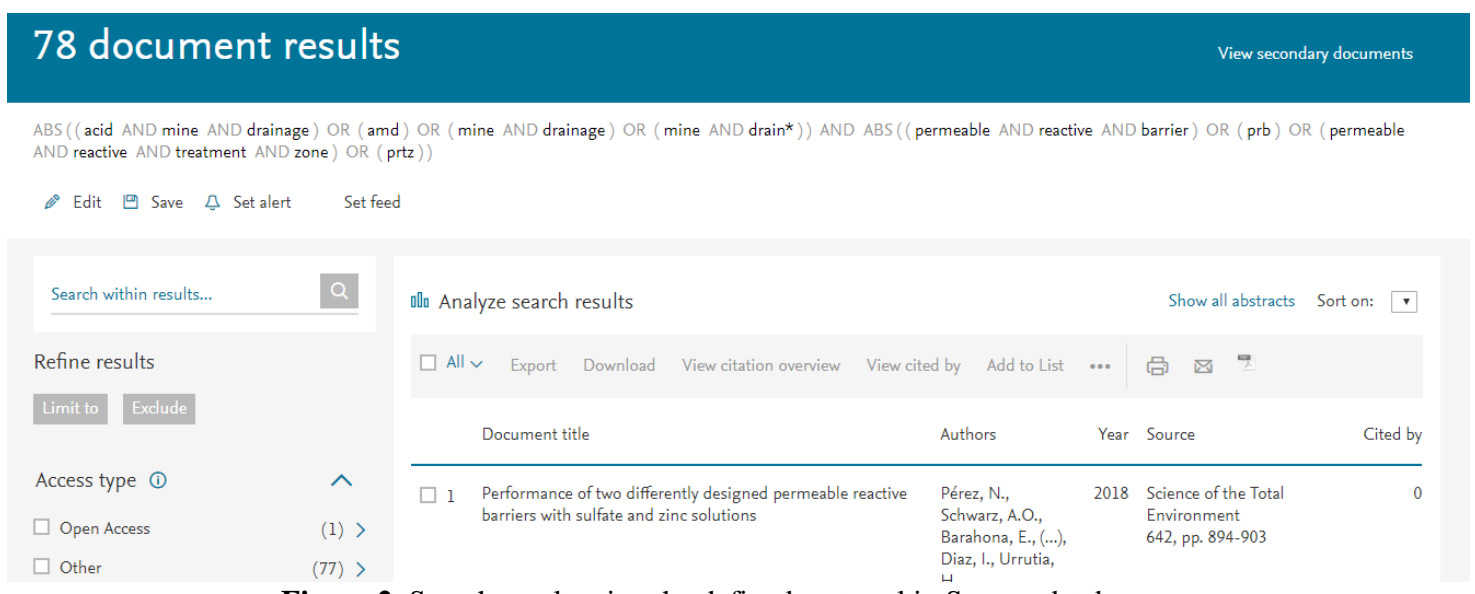

Figure 2. Search result using the defined protocol in Scopus database.
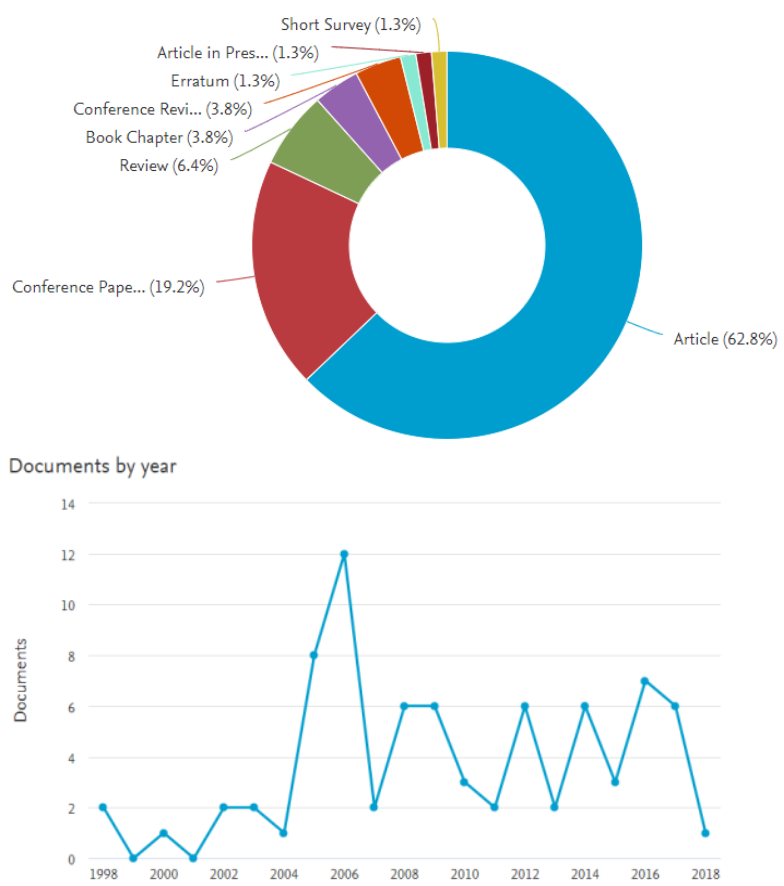

Figure 3. Document review based on (a) type of paper; (b) year published.

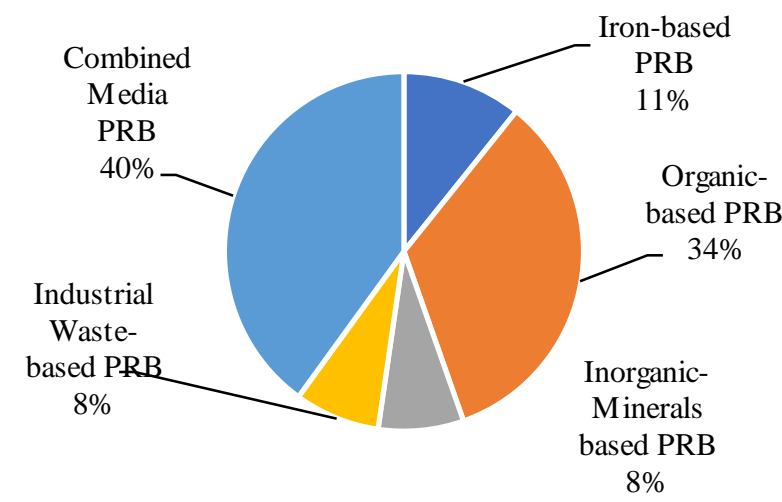

Figure 4. Classification of selected papers based on reactive media.

\subsection{Synthesis}

Permeable reactive barrier is a new remediating technology which can be used for acid mine drainage treatment. Based on the review of current state of the art, the reactive media used in permeable reactive barrier can be categorized into five namely iron-based, organicbased, inorganic minerals-based, industrial waste-based, and combined media.

The typical reactive media used for PRB that has been classified as iron-based is zero-valent iron [6-12]. It has been observed that in high $\mathrm{pH}$ environment, the oxidation of zero-valent iron proceeds slower, thereby could affect the overall performance of the PRB. The occurrence of mutual interactions of various contaminants was impossible to detect based on current methods. Furthermore, degradation of sulfates and nitrates should be improved if the reactive media to be used is zero-valent iron. The recommendation is to include other biotic processes or improve the reducing conditions.

New approaches have been introduced together with the use of organic substrate as reactive media in PRB [13-33]. The results showed that the use of membranefree microbial fuel cell (MFC) for preconditioning has improved the performance of the PRB. The modification of the PRB design by using lattice-layout SRB-PRB has also shown improved efficiency. Understanding the microbiology and kinetics of sulfate-reducing bacteria can help improve the design and operation of the treatment system. This includes methods such as bioaugmentation, biostimulation, and gene profiling. Another notable finding is the use of spatial tracking which provides valuable insight for microbial activity monitoring. The total carbon analysis cannot be used as justification to explain the longevity of the PRB.

Commonly used media that is classified as inorganic minerals-based PRB are limestone, apatite, concrete, manganese, zeolite, and magnesite [34-38]. These materials are composed of calcium, sodium, magnesium and manganese-based minerals which are responsible for the increase in the alkalinity. However, common concern encountered with the use of inorganic minerals is the accumulation of precipitates in the pore spaces which can cause clogging of the pores. It is also worthy to note that the use of concrete-based PRB can result in the formation of gypsum and ettringite. These are undesirable since presence of these compounds can cause cracks and damage in the structure. The use of 
nano-sized inorganic minerals as reactive media can effectively remove the heavy metal such as arsenic [39].

The industrial wastes such as coal fly ash, slag, and bauxsol as reactive media are also a promising alternative [40-44]. These materials neutralize the $\mathrm{pH}$ and effectively remove metals from AMD. However, waste precipitation is a concern as it causes large reduction in hydraulic conductivity of the PRB thereby limiting the efficiency of the treatment system.

Numerous studies have been exploring the use of combined media in PRB $[\mathbf{1 , 3 9 , 4 5 - 6 6}$. The potential of the combination of reactive media has been realized due to its promising performance in terms of removal of sulfates and reduction of toxic metals. For example, the result showed that the permeability coefficient of an iron-based limestone system is better than that of the pristine limestone system [55]. It also improves the retention of redox contaminants. The presence of compost in greatest concentration, presence of biosolids, and zero-valent iron has resulted to a higher sulfate reducing mechanism activity. With these findings, an improved performance and an increase in efficiency is anticipated.

\section{Conclusion}

This study has reviewed the state-of-the-art of the development of permeable reactive barrier for acid mine drainage treatment using systematic mapping approach. The following findings can be drawn:

1. Out of the 78 searched paper based on the defined search protocol, 65 were found to be related and relevant to the scope of the study.

2 . The reactive media used in permeable reactive barrier can be categorized into five namely iron-based, organic-based, inorganic minerals-based, industrial waste-based, and combined media.

3. The data has shown that majority of the papers which is about $40 \%$ uses combined media as the reactive substrate. Published papers that use organic-based PRB is about $34 \%$. Of the relevant papers, $11 \%$ are iron-based PRB. The remaining $16 \%$ is for both inorganic minerals $(8 \%)$ and industrial waste-based PRB (8\%).

4. The future direction is toward the use of combined media as a reactive material for AMD treatment due to the improved performance and efficiency of PRB, for instance, use of geopolymer with mine tailings and silts as reactive media in combination with organicbased media. To date, no studies have been reported yet on the use of geopolymer for AMD treatment.

The authors would like to acknowledge Philippine Council for Industry, Energy and Emerging Technology Research and Development for financially supporting this research under PCIEERD Project No. 07132.

\section{References}

[1] Moodley, I., Sheridan, C.M., Kappelmeyer, U., and Akcil, A. Environmentally sustainable acid mine drainage remediation: Research developments with a focus on waste/by-products, Minerals Engineering 1262018, 207-220.

[2] Akcil, A. and Koldas, S. Acid Mine Drainage (AMD): causes, treatment and case studies, Journal of Cleaner Production 14(12), 2006, 1139-1145.

[3] Marchildon, J. The UN Has Called This The Second Biggest Environmental Problem Facing Our World, Global Poverty Project, Inc 2017, .

[4] James, K.L., Randall, N.P., and Haddaway, N.R. A methodology for systematic mapping in environmental sciences, Environmental Evidence 5(1), 2016, 7.

[5] Petersen, K., Feldt, R., Mujtaba, S., and Mattsson, M. Systematic Mapping Studies in Software Engineering. in: Proc. 12th Int. Conf. Eval. Assess. Softw. Eng., Swindon, UK, BCS Learning \& Development Ltd., pp. 68-77.

[6] Bartzas, G., Komnitsas, K., and Paspaliaris, I. Laboratory evaluation of $\mathrm{Fe} 0$ barriers to treat acidic leachates, Minerals Engineering 19(5), 2006, 505-514.

[7] Fiore, S. and Zanetti, M.C. Preliminary tests concerning zero-valent iron efficiency in inorganic pollutants remediation, American Journal of Environmental Sciences 5(4), 2009, 555-560.

[8] Liendo, M.A., Navarro-Hidalgo, G.E., Sampaio, C.H., and Heck, N.C. Synthesis of ZVI particles for acid mine drainage reactive barriers: Experimental and theoretical evaluation, Journal of Materials Research and Technology 1(2), 2012, 7579.

[9] Suponik, T. and Blanco, M. Removal of heavy metals from groundwater affected by acid mine drainage, Physicochemical Problems of Mineral Processing 50(1), 2014, 359-372.

[10] Suponik, T. Zero-valent iron for removal of inorganic contaminants from low $\mathrm{pH}$ water, Environment Protection Engineering 41(1), 2015, 15-27.

[11] Bilardi, S., Calabró, P.S., and Moraci, N. Simultaneous removal of CUII, NIII and ZNII by a granular mixture of zero-valent iron and pumice in column systems, Desalination and Water Treatment 55(3), 2015, 767-776.

[12] Hudson-Edwards, K.A. and Kossoff, D. Role of redox-reactive minerals in the reuse and remediation of mine wastes, European Mineralogical Union Notes in Mineralogy 172017,

[13] Cai, C.-F., Sun, J., Luo, F.-X., He, S.-S., Hu, S.-H., and $\mathrm{Wu}, \mathrm{B}$. Effects of treatment efficiency of AMD through the PRB based on different structure of MFC, Meitan Xuebao/Journal of the China Coal Society 41(5), 2016, 1301-1308.

[14] Tang, H., Pu, W.-C., Cai, C.-F., Xu, J.-P., and He, W.-J. Remediation of acid mine drainage based on a novel coupled membrane-free microbial fuel cell with permeable reactive barrier system, Polish 
Journal of Environmental Studies 25(1), 2016, 107112.

[15] Place, D.L., Figueroa, L., Wildeman, T., and Reisman, D. Characterizing and tracking reactive mixture alterations: New tools for passive treatment system design and monitoring. in: 7th Int. Conf. Acid Rock Drain. 2006, ICARD - Also Serves as 23rd Annu. Meet. Am. Soc. Min. Reclam., pp. 1605-1619.

[16] Mayer, K.U., Benner, S.G., and Blowes, D.W. Process-based reactive transport modeling of a permeable reactive barrier for the treatment of mine drainage, Journal of Contaminant Hydrology 85(34), 2006, 195-211.

[17] Pereyra, L.P., Hanson, R., Hiibel, S., Pruden, A., and Reardon, K.F. Comparison of inocula applied in the remediation of acid mine drainage by sulfate reduction. in: 22nd Am. Soc. Min. Reclam. Annu. Natl. Conf. 2005, pp. 894-903.

[18] Pruden, A., Hong, H.S., Inman, L.Y., Logan, M. V, Sans, C., Ahmann, D., et al. Microbial characterization of sulfate-reducing columns remediating acid mine drainage. in: $22 \mathrm{nd} \mathrm{Am}$. Soc. Min. Reclam. Annu. Natl. Conf. 2005, pp. 935-944.

[19] Place, D.L., Claveau, E., and Figueroa, L. Tracking organic substrate alterations in passive reactive zones for planning and monitoring. in: 22nd Am. Soc. Min. Reclam. Annu. Natl. Conf. 2005, pp. 921-934.

[20] Logan, M. V, Reardon, K.F., Figueroa, L.A., McLain, J.E.T., and Ahmann, D.M. Microbial community activities during establishment, performance, and decline of bench-scale passive treatment systems for mine drainage, Water Research 39(18), 2005, 4537-4551.

[21] Hemsi, P.S., Shackelford, C.D., and Figueroa, L.A. Modeling the influence of decomposing organic solids on sulfate reduction rates for iron precipitation, Environmental Science and Technology 39(9), 2005, 3215-3225.

[22] Amos, R.T., Mayer, K.U., Blowes, D.W., and Ptacek, C.J. Reactive transport modeling of column experiments for the remediation of acid mine drainage, Environmental Science and Technology 38(11), 2004, 3131-3138.

[23] Gibert, O., de Pablo, J., Cortina, J.L., and Ayora, C. Treatment of acid mine drainage by sulphatereducing bacteria using permeable reactive barriers: A review from laboratory to full-scale experiments, Reviews in Environmental Science and Bio/Technology 1(4), 2002, 327-333.

[24] Waybrant, K.R., Ptacek, C.J., and Blowes, D.W. Treatment of mine drainage using permeable reactive barriers: Column experiments, Environmental Science and Technology 36(6), 2002, 1349-1356.

[25] Mattos, R.C., Hemsi, P.S., Kawachi, E.Y., and Silva, F.T. Use of sugarcane bagasse as carbon substrate in permeable reactive barriers: Laboratory batch tests and mathematical modeling, Soils and Rocks 38(3), 2015, 219-229.

[26] Herbert Jr., R.B., Benner, S.G., and Blowes, D.W.
Reactive barrier treatment of groundwater contaminated by acid mine drainage: Sulphur accumulation and sulphide formation, IAHS-AISH Publication (250), 1998, 451-457.

[27] Pereyra, L.P., Hiibel, S.R., Perrault, E.M., Reardon, K.F., and Pruden, A. Effect of bioaugmentation and biostimulation on sulfate-reducing column startup captured by functional gene profiling, FEMS Microbiology Ecology 82(1), 2012, 135-147.

[28] Kijjanapanich, P., Pakdeerattanamint, K., Lens, P.N.L.L., and Annachhatre, A.P. Organic

substrates as electron donors in permeable reactive barriers for removal of heavy metals from acid mine drainage, Environmental Technology (United Kingdom) 33(23), 2012, 2635-2644.

[29] Zhang, H.-Y., Wang, B., Dong, X.-L., Fan, Z.-M., and Ju, Y.-Y. Feasibility of sewage sludge used as filling material in permeable reactive barrier, Huanjing Kexue/Environmental Science 31(5), 2010, 1280-1286.

[30] Pereyra, L.P., Hiibel, S.R., Pruden, A., and Reardon, K.F. Comparison of microbial community composition and activity in sulfatereducing batch systems remediating mine drainage, Biotechnology and Bioengineering 101(4), 2008, 702-713.

[31] Pruden, A., Pereyra, L.P., Hiibel, S.R., Inman, L.Y., Kashani, N., Reardon, K.F., et al. Microbiology of sulfate-reducing passive treatment systems. in: 7th Int. Conf. Acid Rock Drain. 2006, ICARD - Also Serves as 23rd Annu. Meet. Am. Soc. Min. Reclam., pp. 1620-1631.

[32] Williams, R.L., Mayer, K.U., Amos, R.T., Blowes, D.W., Ptacek, C.J., and Bain, J.G. Using dissolved gas analysis to investigate the performance of an organic carbon permeable reactive barrier for the treatment of mine drainage, Applied Geochemistry 22(1), 2007, 90-108.

[33] Hemsi, P.S., Shackelford, C.D., and Figueroa, L.A. Modeling bioremediation of acid mine drainage in permeable reactive. in: 5th ICEG Environ. Geotech. Oppor. Challenges Responsib. Environ. Geotech. Proc. ISSMGE 5th Int. Congr., pp. 901-908.

[34] Conca, J.L. and Wright, J. An Apatite II permeable reactive barrier to remediate groundwater containing $\mathrm{Zn}, \mathrm{Pb}$ and $\mathrm{Cd}$, Applied Geochemistry 21(8), 2006, 1288-1300.

[35] Wright, J. and Conca, J.L. Remediation of groundwater contaminated with $\mathrm{ZN}, \mathrm{PB}$ and $\mathrm{CD}$ using a permeable reactive barrier with Apatite II. in: 7th Int. Conf. Acid Rock Drain. 2006, ICARD Also Serves as 23rd Annu. Meet. Am. Soc. Min. Reclam., pp. 2514-2527.

[36] Ekolu, S.O., Azene, F.Z., and Diop, S. A concrete reactive barrier for acid mine drainage treatment, Proceedings of the Institution of Civil Engineers: Water Management 167(7), 2014, 373-380.

[37] Liu, J., He, L., Dong, F., and Hudson-Edwards, K.A. The role of nano-sized manganese coatings on bone char in removing arsenic(V) from solution: Implications for permeable reactive barrier technologies, Chemosphere 1532016, 146-154. 
[38] Fedoročková, A., Sučik, G., and Raschman, P. Activated Zeolite and Magnesite as Potential Reactive Materials for Passive Acidic Groundwater Treatment Technology, Solid State Phenomena 2442015, 221-227.

[39] Liu, J., Zhou, L., Dong, F., and Hudson-Edwards, K.A. Enhancing $\mathrm{As}(\mathrm{V})$ adsorption and passivation using biologically formed nano-sized FeS coatings on limestone: Implications for acid mine drainage treatment and neutralization, Chemosphere 1682017, 529-538.

[40] Lapointe, F., Fytas, K., and McConchie, D. Efficiency of Bauxsol $^{\mathrm{TM}}$ in permeable reactive barriers to treat acid rock drainage, Mine Water and the Environment 25(1), 2006, 37-44.

[41] Penney, K., Mohamedelhassan, E., and Catalan, L.J.J. Utilization of coal/biomass fly ash in reactive barriers for treating acid mine drainage. in: Proc. IASTED Int. Conf. Environ. Manag. Eng. EME 2009, pp. 67-73.

[42] Pérez-López, R., Cama, J., Miguel Nieto, J., Ayora, C., and Saaltink, M.W. Attenuation of pyrite oxidation with a fly ash pre-barrier: Reactive transport modelling of column experiments, Applied Geochemistry 24(9), 2009, 1712-1723.

[43] Lapointe, F., Fytas, K., and McConchie, D. Using permeable reactive barriers for the treatment of acid rock drainage, International Journal of Surface Mining, Reclamation and Environment 19(1), 2005, 57-65.

[44] Koshy, N. and Singh, D.N. Fly ash zeolites for water treatment applications, Journal of Environmental Chemical Engineering 4(2), 2016, 1460-1472.

[45] Blowes, D.W., Ptacek, C.J., Benner, S.G., McRae, C.W.T., Bennett, T.A., and Puls, R.W. Treatment of inorganic contaminants using permeable reactive barriers, Journal of Contaminant Hydrology 45(12), 2000, 123-137.

[46] Amos, P.W. and Younger, P.L. Substrate characterisation for a subsurface reactive barrier to treat colliery spoil leachate, Water Research 37(1), 2003, 108-120.

[47] Vestola, E.A. Testing of different substrate materials for sulphate reducing reactive barrier to treat acid mine drainage, Advanced Materials Research 71-732009, 573-576.

[48] Gibert, O., Rötting, T., Cortina, J.L., de Pablo, J., Ayora, C., Carrera, J., et al. In-situ remediation of acid mine drainage using a permeable reactive barrier in Aznalcóllar (Sw Spain), Journal of Hazardous Materials 191(1-3), 2011, 287-295.

[49] Pagnanelli, F., De Michelis, I., Di Tommaso, M., Ferella, F., Toro, L., and Vegliò, F. Treatment of acid mine drainage by a combined chemical/biological column apparatus: Mechanisms of heavy metal removal. Nova Science Publishers, Inc., 2008.

[50] Gibert, O., Cortina, J.L., and Pablo, J.D. Evaluation of sheep manure for In-Situ acid mine drainage treatment. Nova Science Publishers, Inc., 2012.
[51] Jeen, S.-W. and Mattson, B. Evaluation of layered and mixed passive treatment systems for acid mine drainage, Environmental Technology (United Kingdom) 37(22), 2016, 2835-2851.

[52] Huang, J., Zuo, D., and Yue, M. Techniques to treat acid mine drainage: A review. in: Proc. 6th Int. Conf. Environ. Technol. Knowl. Transf., Hefei University, pp. 147-153.

[53] Pérez, N., Schwarz, A.O., Barahona, E., Sanhueza, P., Diaz, I., and Urrutia, H. Performance of two differently designed permeable reactive barriers with sulfate and zinc solutions, Science of the Total Environment 6422018, 894-903.

[54] Beiyuan, J., Tsang, D.C.W., Yip, A.C.K., Zhang, W., Ok, Y.S., and Li, X.-D. Risk mitigation by waste-based permeable reactive barriers for groundwater pollution control at e-waste recycling sites, Environmental Geochemistry and Health 39(1), 2017, 75-88.

[55] Zhou, L., Dong, F., Liu, J., and Hudson-Edwards, K.A. Coupling effect of $\mathrm{Fe} 3+(\mathrm{aq})$ and biological, nano-sized FeS-coated limestone on the removal of redox-sensitive contaminants (As, $\mathrm{Sb}$ and $\mathrm{Cr}$ ): Implications for in situ passive treatment of acid mine drainage, Applied Geochemistry 802017, 102 111.

[56] Jeen, S.-W., Bain, J.G., and Blowes, D.W. Evaluation of mixtures of peat, zero-valent iron and alkalinity amendments for treatment of acid rock drainage, Applied Geochemistry 432014, 6679.

[57] Gibert, O., Cortina, J.L., de Pablo, J., and Ayora, C. Performance of a field-scale permeable reactive barrier based on organic substrate and zero-valent iron for in situ remediation of acid mine drainage, Environmental Science and Pollution Research 20(11), 2013, 7854-7862.

[58] Shabalala, A.N. Assessment of locally available reactive materials for use in permeable reactive barriers (PRBs) in remediating acid mine drainage, Water SA 39(2), 2013, 251-256.

[59] Gibert, O., De Pablo, J., Cortina, J.L., and Ayora, C. Evaluation of municipal compost/limestone/iron mixtures as filling material for permeable reactive barriers for in-situ acid mine drainage treatment, Journal of Chemical Technology and Biotechnology 78(5), 2003, 489-496.

[60] Pérez, N.R., Schwarz, A.O., and Urrutia, H. Treatment of acid mine drainage: Study of sulphate reduction in organic mixtures. [Tratamiento del drenaje ácido de minas: estudio de reducción de sulfato en mezclas orgánicas], Tecnologia y Ciencias Del Agua 8(1), 2017, 63-64.

[61] Di, J., Jiang, F., Zhu, Z., Dai, N., and Guo, X. In-situ restoration of acid mine drainage by $\mathrm{PRB}$ cooperated with $\mathrm{Fe} 0$ and biological maifan stone, Chinese Journal of Environmental Engineering 8(12), 2014, 5111-5116.

[62] Ardau, C., Lattanzi, P., Peretti, R., and Zucca, A. Chemical stabilization of metals in mine wastes by transformed red mud and other iron compounds: Laboratory tests, Environmental Technology 
(United Kingdom) 35(24), 2014, 3060-3073.

[63] Xu, Z., Wu, Y., and Yu, F. A Three-Dimensional Flow and Transport Modeling of an Aquifer Contaminated by Perchloroethylene Subject to Multi-PRB Remediation, Transport in Porous Media 91(1), 2012, 319-337.

[64] Guo, Q. and Blowes, D.W. Biogeochemistry of two types of permeable reactive barriers, organic carbon and iron-bearing organic carbon for mine drainage treatment: Column experiments, Journal of Contaminant Hydrology 107(3-4), 2009, 128-139.

[65] Sasaki, K., Nukina, S., Wilopo, W., and Hirajima, T. Removal of arsenate in acid mine drainage by a permeable reactive barrier bearing granulated blast furnace slag: Column study, Materials Transactions 49(4), 2008, 835-844.

[66] Sasaki, K., Blowes, D.W., and Ptacek, C.J. Spectroscopic study of precipitates formed during removal of selenium from mine drainage spiked with selenate using permeable reactive materials, Geochemical Journal 42(3), 2008, 283-294. 